\title{
Moenkhausia rubra, a new species from rio Juruena, upper rio Tapajós basin, Brazil (Characiformes: Characidae)
}

\author{
Murilo N. L. Pastana ${ }^{1}$ and Fernando C. P. Dagosta ${ }^{2}$
}

Moenkhausia rubra, new species, is described from the upper rio Juruena, rio Tapajós basin, Mato Grosso, Brazil. The new species is distinguished from its congeners, except $M$. hemigrammoides and M. nigromarginata, by the dark pigmentation on the anteriormost rays of both dorsal and anal fins. Moenkhausia rubra is distinguished from the aforementioned species by the number of branched anal-fin rays 17-20 (vs. 20-25), presence of a dark blotch on the caudal peduncle extending to middle caudal-fin rays, absence of longitudinal black zigzag stripes between longitudinal rows of scales on body, and other details of coloration.

Moenkhausia rubra, espécie nova, é descrita do alto rio Juruena, bacia do rio Tapajós, Mato Grosso, Brasil. A espécie nova diferencia-se de todos os congêneres, exceto $M$. hemigrammoides e $M$. nigromarginata, pela presença de pigmentação escura nos raios mais anteriores das nadadeiras dorsal e anal. Moenkhausia rubra distingui-se das espécies acima mencionadas pelo número de raios ramificados na nadadeira anal 17-20 (vs. 20-25), presença de uma mancha escura no pedúnculo caudal se estendendo até os raios medianos da nadadeira caudal, ausência de faixas em zigue-zague longitudinais entre as séries longitudinais de escamas no corpo, além de outros detalhes de coloração.

Key words: Amazon, Moenkhausia nigromarginata, Neotropical fishes, Ostariophysi, Tetra.

\section{Introduction}

The genus Moenkhausia Eigenmann currently comprises over seventy valid species (Bertaco et al., 2011a, 2011b; Mariguela et al., 2013) presenting a wide variation in overall shape and pigmentation patterns (Benine et al., 2004), many of which have been described recently (e.g., Benine et al., 2009; Zanata et al., 2009; Marinho, 2010; Marinho \& Langeani, 2010; Sousa et al., 2010; Bertaco et al., 2011a, 2011b). The genus is widely distributed in South America, being present in coastal drainages of the Guyanas, as well as in the río Orinoco, rio Amazonas, rio Tocantins and Araguaia, rio São Francisco, rio Paraná-Paraguay, and Brazilian eastern drainages (Lima et al., 2003).

According to recent phylogenetic studies (e.g., Mirande, 2010; Oliveira et al., 2011; Mariguela et al., 2013) Moenkhausia is not a monophyletic group, as previously suggested by Fink (1979), Costa (1994) and Weitzman \& Palmer (1997). However, these phylogenetic studies included restricted numbers of species of Moenkhausia, and a phylogeny encompassing the whole diversity of the group is still lacking. In the absence of a phylogenetic definition, several authors still use the characters proposed by Eigenmann (1917) to allocate new species in Moenkhausia (e.g., Zanata et al., 2009; Marinho \& Langeani, 2010; Bertaco et al., 2011a, 2011b).

During identification of material deposited in Laboratório de Ictiologia de Ribeirão Preto (LIRP), an undescribed species of Moenkhausia was recognized from rio Juruena, rio Tapajós basin, which is herein formally described.

\section{Material and Methods}

Morphometric and meristic data follow Fink \& Weitzman (1974) except for counts of scale rows, which follow Lima et al. (2007) and with the addition of pelvic-fin origin to anal-fin origin measured at origin of pelvic-fin through the anal-fin origin. Measurements were taken with a digital caliper. Standard length (SL) is given in millimeters (mm), and

\footnotetext{
${ }^{1}$ Laboratório de Ictiologia de Ribeirão Preto, Universidade de São Paulo, FFCLRP, Departamento de Biologia. Av. dos Bandeirantes, 3900, 14040-901 Ribeirão Preto, SP, Brazil. murilo_pastana@hotmail.com

${ }^{2}$ Museu de Zoologia da Universidade de São Paulo. Caixa Postal 42494, 04218-970 São Paulo, SP, Brazil. ferdagosta@gmail.com
} 
morphometric data is given as percentage of SL, or head length for head subunits. The vertebrae of the Weberian apparatus were counted as four elements, and the PU1 + U1 as one element. Counts of maxillary teeth cusps, number and cusps of small dentary teeth, vertebrae, supraneurals, pterygiophores of dorsal and anal fins, procurrent caudal-fin rays, and gill-rakers of the first gill-arch were taken from cleared and stained (c\&s) paratypes prepared following the method of Taylor \& Van Dyke (1985). Sex was determined based on the pelvic-fin elongation and confirmed by direct examination of gonads in 10 specimens following the methodology described by Vazzoler (1996). In the description, counts are followed by their frequencies in parentheses with an asterisk indicating the count of the holotype. Institutional abbreviations follow Ferraris Jr. (2007).

\section{Moenkhausia rubra, new species}

Figs. 1-3

Holotype. LIRP 8183, 41.3 mm SL, Brazil, Mato Grosso, município de Sapezal, Pequena Central Hidroelétrica (PCH) Sapezal, rio Juruena, rio Tapajós basin, 13²16’10"S 5901'26"W, 01 May 2010, R. Ilário.

Paratypes. LIRP 7657, 1, $31.1 \mathrm{~mm}$ SL, Brazil, Mato Grosso, município de Sapezal, rio Juruena, rio Tapajós basin,13²2’39"S 5900’58"W, 23 May 2008, R. Ilário. LIRP 8164, 8, 36.5-54.3 mm SL, Brazil, Mato Grosso, município de Sapezal, rio Juruena, rio Tapajós basin, PCH Parecis, 1304’43"S 5858’06"W, 24 May 2010, R. Ilário. LIRP 8177, 6, 37.1-47.2 mm SL, 1 c\&s, 45.8 mm SL, Brazil, Mato Grosso, município de Sapezal, rio Juruena, rio Tapajós basin, PCH Cidezal, 13²2’39"S 5900’57"W, 3 Jun 2010, R. Ilário. LIRP 8178, 8, 32.7-47.91 mm SL; 1 c\&s, 40.7 mm SL, Brazil, Mato Grosso, município de Sapezal, rio Juruena, rio Tapajós basin, collected with holotype, $13^{\circ} 16^{\prime} 10^{\prime \prime S} 59^{\circ} 01^{\prime} 26^{\prime \prime} \mathrm{W}, 01$ May 2010, R. Ilário. LIRP 8180, 19, 18.9-28.8 mm SL, Brazil, Mato Grosso, município de Sapezal, rio Juruena, rio Tapajós basin, PCH Cidezal, small beach on the side of a rapid, $13^{\circ} 22^{\prime} 20^{\prime \prime} S 59^{\circ} 00^{\prime} 51^{\prime \prime W}, 05$ Jan 2008, R. Ilário. MZUSP 109218, 3, 36.5-39 mm SL, Brazil, Mato Grosso, município de Sapezal, rio Juruena, rio Tapajós basin, PCH Cidezal, 13²2’39"S 5900’57"W, 3 Jun 2010, R. Ilário. MZUSP 114032, 1, 39.8 mm SL, Brasil, Mato Grosso, Campos de Júlio, rio Juína, tributary of rio Juruena, rio Tapajós basin, 1347’41"'S 59²7’20’'W, 8 Set 2013, O. T. Oyakawa, F. C. P. Dagosta, M. M. F. Marinho \& P. Camelier.

Diagnosis. Moenkhausia rubra is distinguished from all congeners, except $M$. hemigrammoides Géry and $M$. nigromarginata Costa, by the presence of dark pigmentation on the anteriormost rays of dorsal and anal fins. It can be distinguished from $M$. hemigrammoides and $M$. nigromarginata by the number of branched anal-fin rays 17 20 (vs. 20-22 in M. nigromarginata and 22-25 in $M$. hemigrammoides). It can be further distinguished from $M$. hemigrammoides by the presence of a dark blotch on the caudal peduncle extending to middle caudal-fin rays ( $v s$. absence) and from $M$. nigromarginata by the absence of dark pigmentation on the anteriormost pelvic fin rays (vs. dark pigmentation present), absence of dark pigmentation along the distal margin of anal fin (vs. presence) and absence of longitudinal black zigzag stripes between longitudinal rows of scales on body (vs. presence). Moenkhausia rubra can also be distinguished from its congeners by the combination of the following characters: 5 or 6 scale rows above and 4 or 5 scale rows below the lateral line, 17-20 branched anal-fin rays, 33-34 lateral line scales, 3-6 maxillary teeth, one round humeral spot, absence of reticulated color pattern on body, absence of a dark broad stripe extending from the opercle to the caudal peduncle, distal portion of caudal-fin lobes hyaline, and dark caudal-peduncle spot extending posterior to the middle caudal-fin rays.

Description. Morphometric data of M. rubra in Table 1. Smallsized species, largest examined specimen $54.3 \mathrm{~mm}$ SL (LIRP 8164). Body compressed and moderately deep (Fig. 1). Greatest body depth slightly anterior to dorsal-fin insertion. Dorsal profile of head strongly convex from snout tip to vertical through nostrils, straight to slightly concave from that point to tip of supraocciptal spine; convex from tip of supraoccipital spine to dorsal-fin origin. Dorsal-fin straight along its base, straight to slightly convex from dorsal-fin terminus to adiposefin origin, concave between latter and origin of anteriormost dorsal caudal-fin procurrent ray. Ventral profile of head convex from tip of snout to pelvic-fin origin, slightly straight from pelvic-fin origin to anal-fin origin, straight along anal-fin base, posterodorsally inclined, concave between last anal-fin ray to anteriormost ventral caudal-fin procurrent ray.

Mouth terminal. Posterior margin of maxilla approximately at vertical through middle of orbit. Premaxillary teeth in two rows. Outer premaxillary tooth row with $4(13)$ or $5 *(15)$ tricuspid teeth with median cusp more developed than others (Fig. 2); inner tooth row with $5^{*}(28)$ pentacuspid teeth. Premaxillary teeth gradually decreasing in size laterally. Maxilla with 3(1), 4(3), 5*(18), or 6(6) uni- to tricuspid teeth. Dentary with $4 *(27)$ or $6(1)$, pentacuspid teeth followed by a series of 10-15 small conical teeth (Fig. 2). First gill arch with 17(2) gill rakers, 6 (2) rakers on epibranchial, 1 (2) between epibranchial and ceratobranchial, 8 (2) on ceratobranchial, 1 (2) between ceratobranchial and hypobranchial, and 1 (2) on hypobranchial. Four branchiostegal rays (2): three branchiostegal rays articulating with anterior ceratohyal and one with posterior ceratohyal.

Scales cycloid, without circuli on exposed portion of scales, usually up to 6 divergent radii extending to posterior margin of scale. Lateral line complete, slightly curved ventrally, with $33 *(11)$ or $34(15)$ pored scales on longitudinal series. Scale rows between dorsal-fin origin and lateral line 6 (26) or $5^{*}(2)$; scale rows between lateral line and pelvic-fin origin 5*(27) or 4(1). Predorsal scales 8(1), 9*(13), 10(11), or 11(1). Circumpeduncular scale rows $14 *(21)$ or $15(1)$.

Pectoral-fin rays i,10(2), i,11*(24) or i,12(2) rays reaching pelvic-fin origin. Pelvic-fin rays i, $7^{*}(28)$, reaching origin of anal fin in some specimens. Supraneurals 4(2). Dorsal-fin rays ii,9*(28), first unbranched anal-fin ray about one-half the length of second unbranched ray. Dorsal-fin origin at 


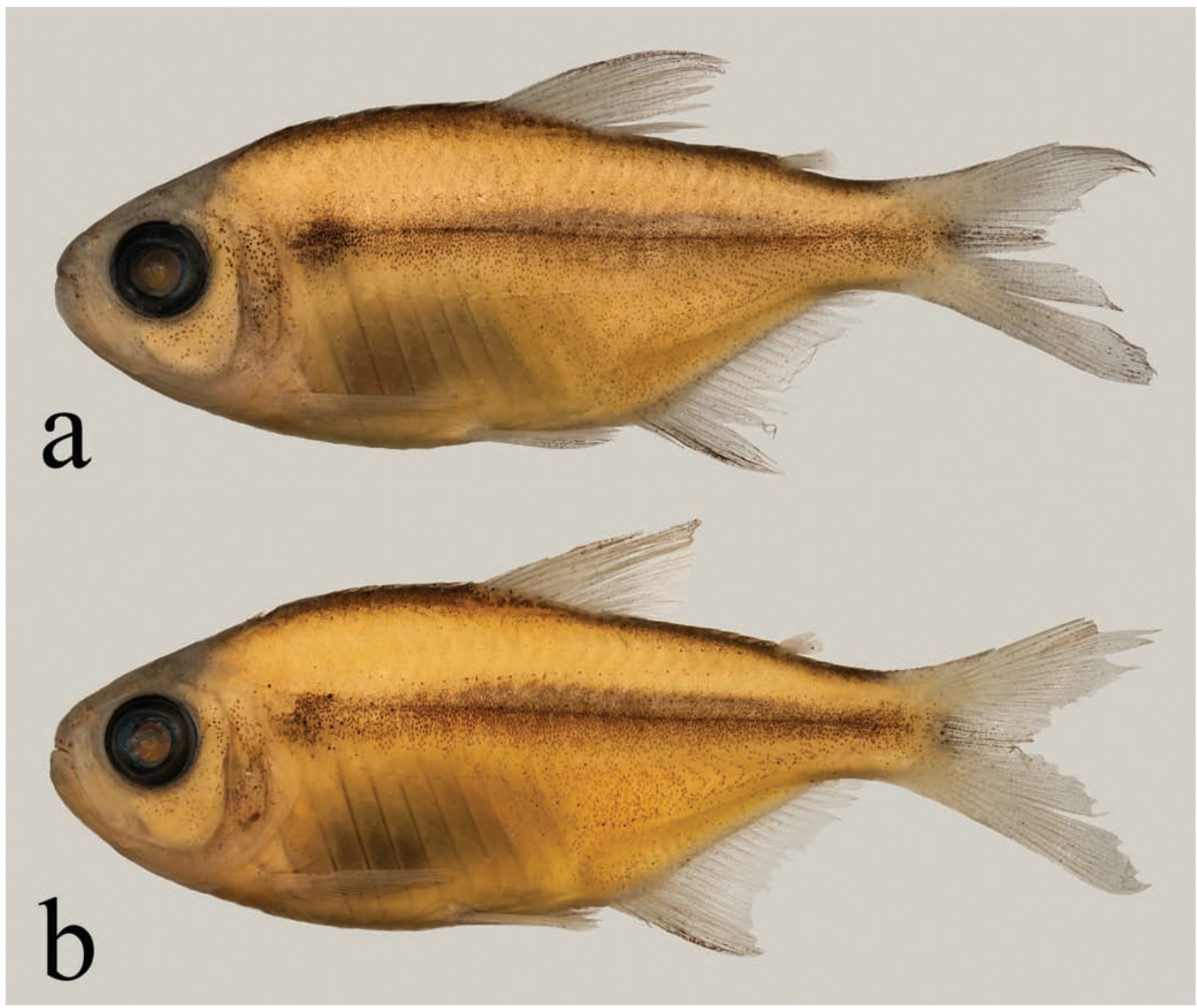

Fig. 1. Moenkhausia rubra, Brazil, Mato Grosso, Sapezal, Pequena Central Hidrelétrica (PCH) Sapezal, rio Juruena, rio Tapajós basin: (a) LIRP 8183, holotype, female, 41.3 mm SL, (b) LIRP 8164, paratype, male, 47.4 mm SL.

midbody, slightly posterior to vertical through pelvic-fin origin, base of posteriormost dorsal-fin ray slightly anterior to vertical through anal-fin origin. First dorsal-fin pterygiophore inserting posterior to neural spine of $9^{\text {th }}(2)$ vertebrae. Adipose fin present. Anal-fin rays iii,17(3), iii,18(8)*, iii,19(14) or iii,20(2). Distal border of anal fin concave. Caudal fin forked, with scales covering proximal half of caudal-fin lobes. Principal caudalfin rays i,9/8,i* (28). Dorsal caudal-fin procurrent rays $13(2)$ and ventral caudal-fin procurrent rays 10(1) or 11(1). Precaudal vertebrae 14 (2), caudal vertebrae 18 (2), total vertebrae 32 (2).

Color in alcohol. Background body coloration pale yellow (Fig. 1). Dorsal and dorsolateral portion of head grey with dark chromatophores scattered on dorsal surface of head, opercle and infraorbital bones. High concentration of dark chromatophores on dorsal midline of body, from tip of supraoccipital spine to anteriormost dorsal procurrent ray.
Diffuse, dark and round humeral spot with borders not well delimited, extending horizontally along two to three scales, and vertically by three scale rows. Diffuse longitudinally stripe extending along flanks from humeral spot to median caudal-fin rays, more diffuse anteriorly, gradually wider posteriorly. Stripe wider at caudal peduncle and extending onto middle caudal-fin rays. Unbranched and first to third anteriormost branched dorsal-fin rays with dark chromatophores along its length, densely concentrated on its distal portion; remaining rays with few scattered dark chromatophores along their length. Unbranched and first to fifth anteriormost branched anal-fin rays with dark chromatophores along their length, densely concentrated on distal portion; remaining rays with few scattered dark chromatophores along its length. Caudal, pectoral, and pelvic fins with few scattered dark chromatophores mainly on interradial membranes. 


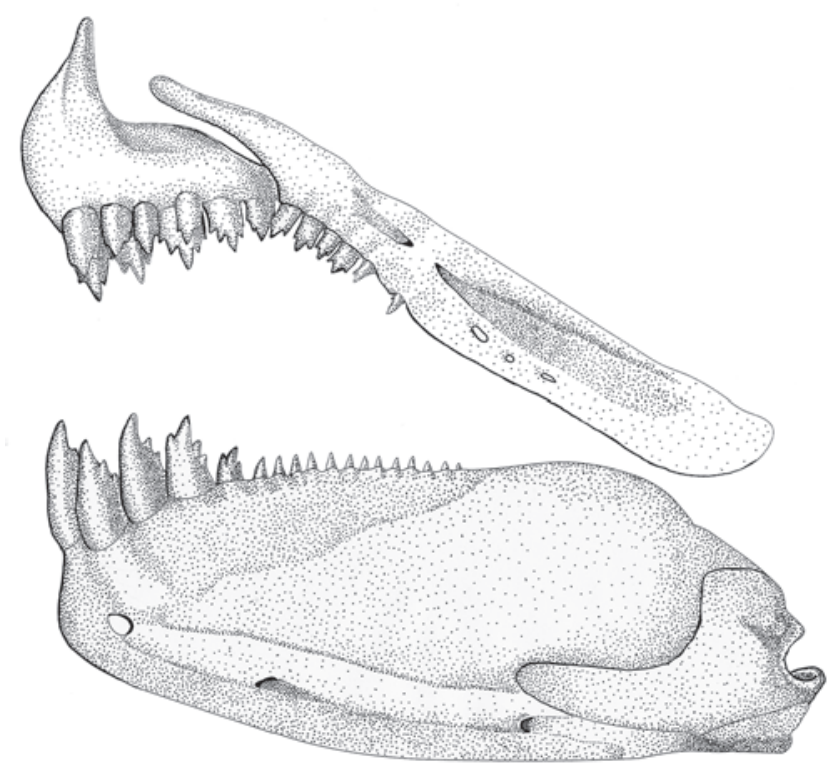

Fig. 2. Moenkhausia rubra, paratype, lateral view of left side of upper and lower jaws, LIRP 8178, 40.7 mm SL.

Color in life. Overall background color ranging from yellowish to reddish, mainly on mid-dorsal area (Fig. 3). Midventral area silvery. Snout and gular area orange. Eye mostly orange, dorsal portion blue to green. Opercular region and circumbital bones silvery. Dark longitudinal stripe at mid-body. Humeral spot round and diffuse. Pectoral and pelvic fins hyaline. Anal and dorsal fins with unbranched and first to third branched anteriormost rays with dark marks. Dorsal, adipose, and caudal

Table 1. Morphometric data of holotype (H) and paratypes of Moenkhausia rubra from Mato Grosso, upper rio Juruena, rio Tapajós drainage $(\mathrm{n}=28)$. $\mathrm{SD}=$ standard deviation.

\begin{tabular}{lcccc}
\hline & $\mathrm{H}$ & Range & Mean & SD \\
\hline $\begin{array}{l}\text { Standard length (mm) } \\
\quad \text { Percents of standard length }\end{array}$ & 41.3 & $32.7-54.3$ & 45.1 & - \\
Body depth & 39.2 & $36.0-42.1$ & 39.1 & 1.6 \\
Predorsal distance & 53.1 & $50.8-55.8$ & 52.1 & 1.0 \\
Prepelvic distance & 51.4 & $49.4-53.4$ & 51.0 & 1.0 \\
Prepectoral distance & 29.6 & $28.2-30.9$ & 29.7 & 0.7 \\
Preanal distance & 68.8 & $66.1-69.6$ & 68.1 & 0.8 \\
Pelvic-fin origin to anal-fin origin & 19.1 & $17.4-19.7$ & 18.7 & 0.7 \\
Caudal peduncle depth & 12.0 & $11.3-12.6$ & 12.1 & 0.3 \\
Caudal peduncle length & 13.8 & $11.7-15.1$ & 13.5 & 0.9 \\
Dorsal-fin base & 13.2 & $13.2-14.8$ & 14.1 & 0.4 \\
Anal-fin base & 27.1 & $24.7-28.3$ & 26.7 & 1.0 \\
Dorsal-fin origin to caudal-fin origin & 52.4 & $51.3-55.8$ & 53.1 & 1.0 \\
Pectoral-fin length & 20.4 & $20.1-24.7$ & 22.9 & 1.3 \\
Pelvic-fin length & 16.6 & $14.7-19.5$ & 17.4 & 1.1 \\
Dorsal-fin length & 25.0 & $24.9-30.4$ & 27.7 & 1.4 \\
Eye to dorsal-fin origin & 38.8 & $36.6-40.7$ & 38.7 & 0.9 \\
Anal-fin length & 17.5 & $15.0-20.7$ & 17.8 & 1.5 \\
Head length & 29.0 & $27.4-30.4$ & 29.2 & 0.7 \\
& & & & \\
Snout length & & & & \\
Orbital diameter & 24.7 & $21.4-25.2$ & 23.4 & 1.0 \\
Upper jaw length & 38.0 & $35.0-41.0$ & 38.3 & 1.5 \\
Interorbital width & 49.9 & $46.9-51.1$ & 49.0 & 1.1 \\
\hline
\end{tabular}
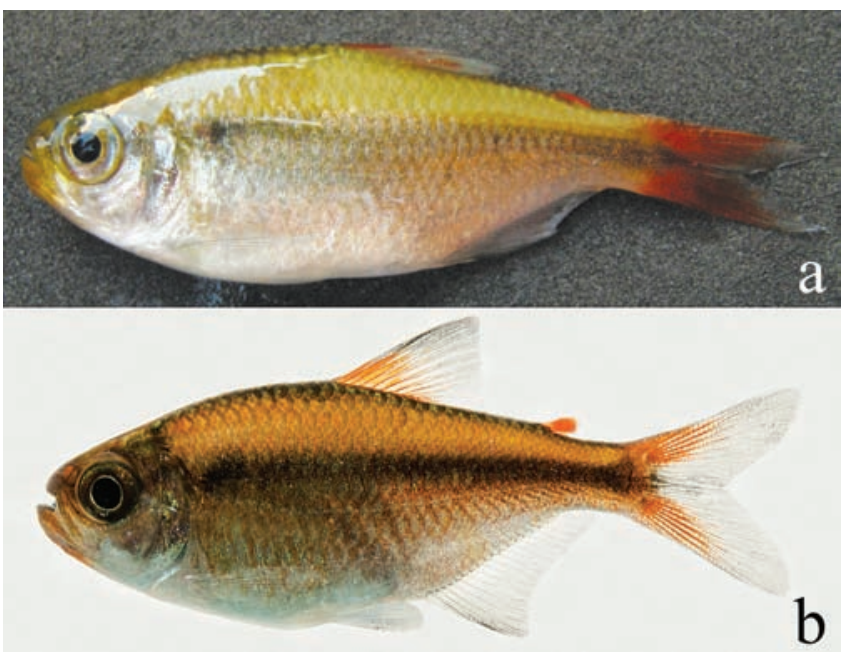

Fig. 3. Moenkhausia rubra, paratypes: (a) LIRP 8180, 29.1 mm SL, Brazil, Mato Grosso, Sapezal, rio Juruena, immediately after capture; (b) MZUSP 114032, 39.8 mm SL, Brazil, Mato Grosso, Campos de Júlio, rio Juína, immediately after capture.

fins intense orange to reddish, except for distal hyaline portion on dorsal and caudal fins.

Sexual dimorphism. Males and females/immature specimens were sexed based on the pelvic-fin elongation (Fig. 4). Sex was confirmed by dissection in 10 specimens (male $n=5$; female $n=5$ ). Adult males with pelvic-fin rays slightly longer than females or juvenile specimens, with pelvic-fin length ranging from 17.4-19.5\% of SL in mature males (vs. 14.7-17.6\% $\mathrm{SL}$ in mature females/immature specimens). Bony hooks were not observed on fins of any analyzed specimen.

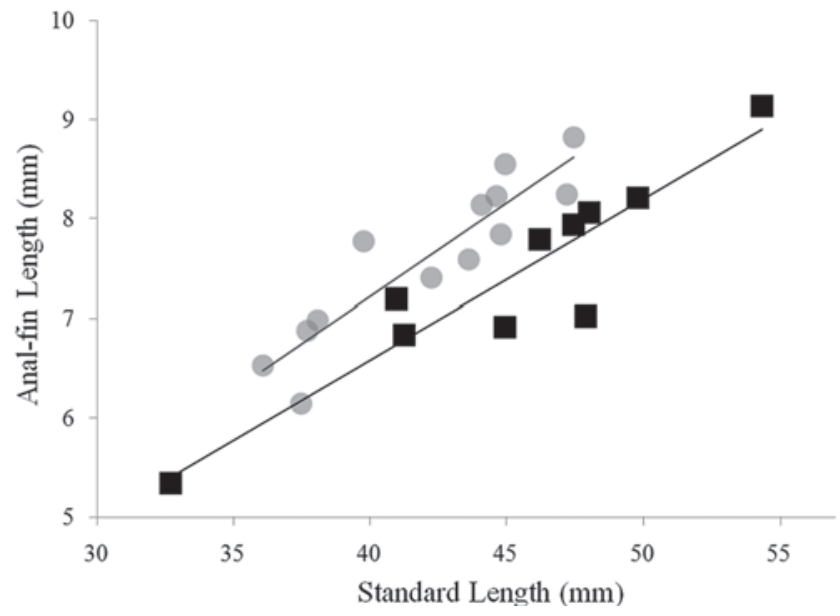

Fig. 4. Moenkhausia rubra, pelvic-fin length as function of standard length by sex and maturity. Gray circles $=$ males $(\mathrm{n}=$ $13)$; black squares $=$ females $/$ immature specimens $(n=10)$. 


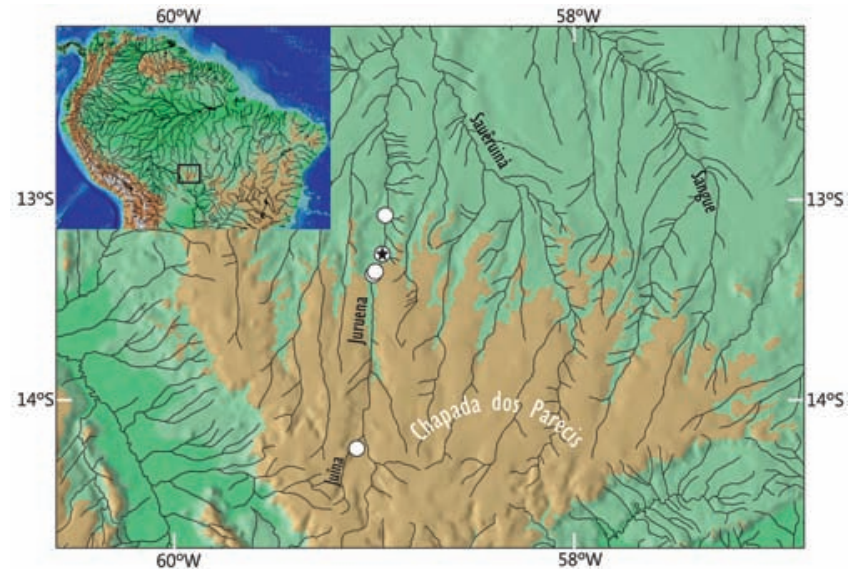

Fig. 5. Distribution of Moenkhausia rubra. Black star represents type locality. Symbols may represent more than one lot.

Distribution. Moenkhausia rubra is known from rio Juína and rio Juruena, rio Juruena basin, upper rio Tapajós drainage, Mato Grosso State, Brazil (Fig. 5).

Etymology. From the latin ruber (red), in allusion to the reddish coloration of the body, and the dorsal, adipose, and caudal fins in live specimens. An adjective.

\section{Discussion}

Although some recent works dealing with the phylogeny of the Characidae have included species of Moenkhausia (e.g., Mirande, 2010; Oliveira et al., 2011, Mariguela et al., 2013), no published account has delved into the definition of the genus which therefore still lacks a phylogenetic definition. Thus, the new species described is herein assigned to Moenkhausia according to the traditional definition of the genus proposed by Eigenmann (1917).

Overall body and life coloration of Moenkhausia rubra resembles $M$. aurantia Bertaco, Jerep \& Carvalho and $M$. nigromarginata (Fig. 6), both from upland areas of the Brazilian shield (M. aurantia: upper rio Tocantins basin and M. nigromarginata: upper rio Tapajós basin). The new species differs from M. aurantia by the presence of dark pigmentation on the anteriormost rays of anal and dorsal fins and by having fewer number of branched anal-fin rays 17-20 (vs. 21 or more). Moenkhausia rubra is further distinguished from $M$. aurantia by the length of the anal fin ranging from $24.7-28.3 \%$ of SL (vs. 30.8-35.7\% of SL), and by having the pectoral, pelvic and anal fins hyaline in life (vs. reddish). The new species can be diagnosed from $M$. nigromarginata by the absence of longitudinal black zigzag stripes on both sides of body ( $v s$. presence), and by the absence of dark pigmentation on lateralmost rays of pectoral fins (vs. presence).

The new species was syntopically collected with six other congeners: Moenkhausia lopesi Britski \& Silimon, M. cosmops Lima, Britski \& Machado, M. cotinho Eigenmann, $M$. oligolepis Günther, M. phaeonota Fink, and M. pirauba
Zanata, Birindelli \& Moreira. Besides the absence of dark pigmentation on the anteriormost rays of dorsal and anal fins of the aforementioned species, $M$. rubra is readily distinguished from M. cosmops, $M$. oligolepis, and M. pirauba by having 33-34 scales scales on longitudinal series (vs. 32 or fewer in $M$. cosmops, $M$. oligolepis, and 43 or more in $M$. pirauba), from $M$. cotinho by the caudal spot extending posteriorly to the distal margins of the middle caudal-fin rays (vs. not reaching the distal tip of the middle caudal-fin rays), from $M$. lopesi by the presence of a dark and round humeral spot (vs. humeral spot absent), and from $M$. phaeonota by the absence of a dark, broad stripe, from the opercle to the end of the caudal peduncle (vs. presence).

In most characids the dorsal and anal fins are hyaline (e.g., Géry, 1977), however several species (e.g., "rosy tetra" species) present dark pigmentation in these fins ranging in size, shape, and position of marks. The evolutionary meaning of these characters have been little studied in Characidae, yet the presence of dark marks in fins seems to have been independently acquired in different lineages of characids. The presence of dark pigmentation along the length of first rays of both the dorsal and anal fins, as found in Moenkhausia rubra (Fig. 1), is uncommon among other Moenkhausia species, with only $M$. hemigrammoides and $M$. nigromarginata (Fig. 6b) presenting a condition that resembles the one found on the new species. Nevertheless, the position and shape of the dark marks on the dorsal and anal fins of $M$. hemigrammoides are similar to the condition found in Hemigrammus unilineatus (Gill), and differs from that seen in $M$. rubra and $M$. nigromarginata. In $M$. hemigrammoides the dark mark of the dorsal fin covers all the dorsal-fin rays ( $v s$. covering up to four anteriormost dorsalfin rays in M. rubra and M. nigromarginata) and the anal-fin dark mark is oblique to the main axis of the fin (vs. perpendicular to the main axis in M. rubra and M. nigromarginata).

The ichthyofauna of the upper rio Tapajós drainage is poorly known (Bertaco \& Garutti, 2007; Britski \& Lima, 2008) and highly endemic (Lima et al., 2007; Britski \& Lima, 2008). The description of $M$. rubra and many other species in the last decade (e.g., Britski \& Garavello, 2005; Bertaco \& Carvalho, 2005a; 2005b; Fisch-Muller et al., 2005; Vari et al., 2005; Carvalho \& Bertaco, 2006; Menezes, 2006; Bertaco \& Garutti, 2007; Bertaco \& Malabarba, 2007; Britski \& Garavello, 2007; Britski \& Lima, 2008; Scharcansky \& Lucena, 2007; Ferreira \& Netto-Ferreira, 2010; Sousa et al., 2010; Carvalho \& Datovo, 2012; Varella et al., 2012), all restricted to the upper rio Tapajós, confirm both facts.

Comparative material examined. Astyanax anterior: Brazil: Pará: MZUSP 99853, 1, 59.96 mm SL, Jacareacanga, rio TelesPires, rio Tapajós basin. Astyanax argyrimarginatus: Brazil: Mato Grosso: MZUSP 88276, 1, 45.29 mm SL, Gaúcha do Norte, rio Culuene, rio Xingu basin. Astyanax novae: Brazil: Maranhão: MZUSP 87287, 1, 33.08 mm SL, Estreito, rio Tocantins basin. Astyanax saltor: Brazil: Pará: MZUSP 101440, 1, 59.02 mm SL, Novo Progresso, Teles-Pires, rio Tapajós basin. Astyanax scintillans: Brazil: Tocantins: MZUSP 113847, 2, 26.78-29.99 


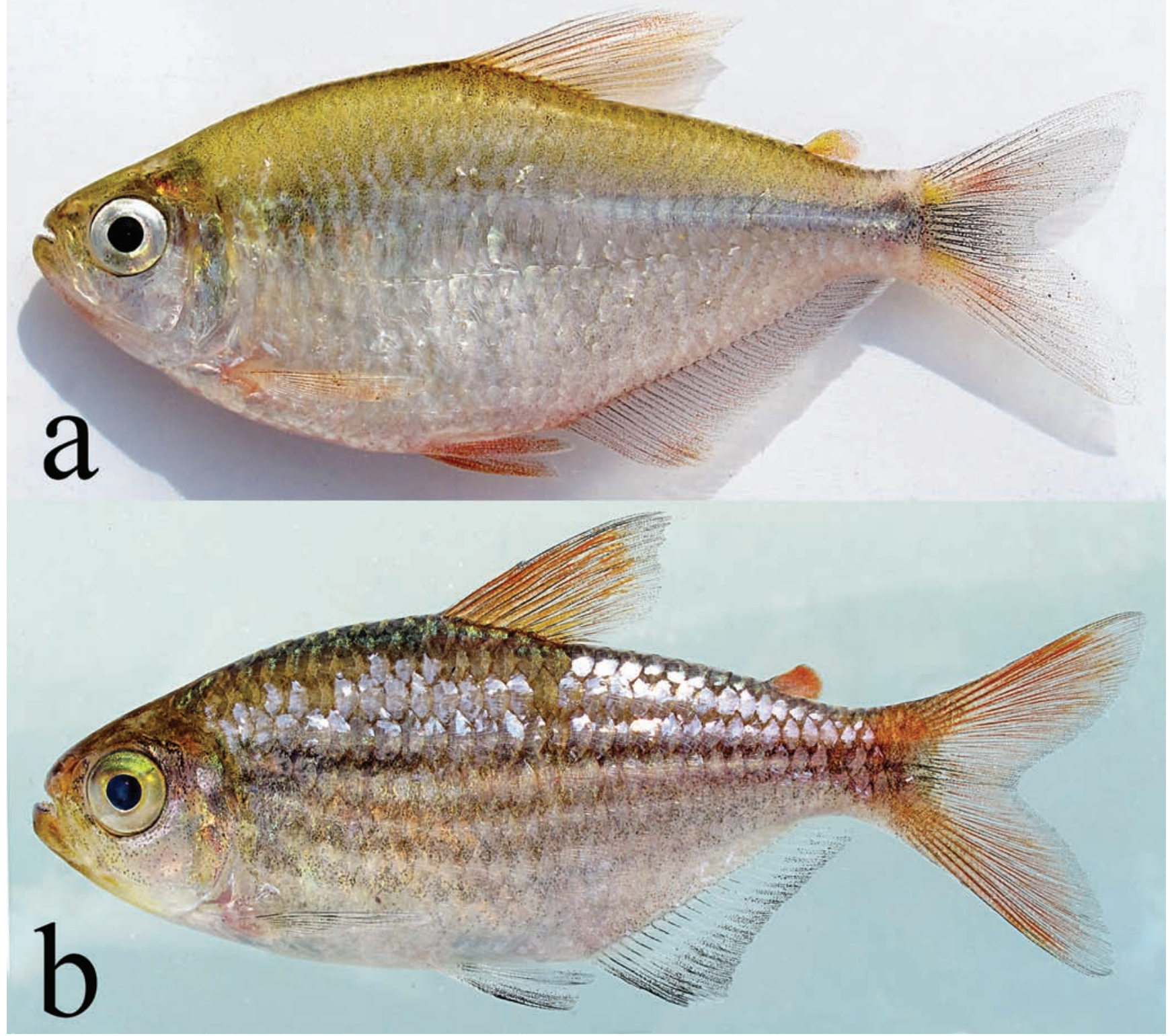

Fig. 6. Live specimens of: (a) Moenkhausia aurantia, MZUSP 113835, 48.3 mm SL, Brazil, Goiás, rio Tocantins basin; (b) Moenkhausia nigromarginata, MZUEL 8009, 50.0 mm SL, Brazil, Mato Grosso, rio Tapajós basin.

mm SL, Conceição do Tocantins, rio Palmas, rio Tocantins basin. Paratypes of Erythrocharax altipinnis Netto-Ferreira, Birindelli, Sousa, Mariguela \& Oliveira, 2013: Brazil: Pará: MZUSP 110999, 2, 26.17-22.82 mm SL, Altamira, rio Curuá, rio Xingu basin. Gymnocorymbus thayeri: Brazil: Amazonas: MZUSP 92494, 9, 63.35-33.07 mm SL, Igarapé Castanha, rio Negro basin. Hemigrammus belotii: Brazil: Roraima: MZUSP 113274, 1, 22.84 mm SL, Caracaraí, Caicubi stream, rio Branco basin. Hemigrammus brevis: Brazil: Bahia: MZUSP 42198, 6, 14.61-21.97 mm SL, Ibraba, rio São Francisco basin. Hemigrammus erythrozonus: Guiana: Potaro-Siparuni: MZUSP 108875, 2, 20.59-20.74 mm SL, rio Kuribrong, rio Essequibo basin. Hemigrammus geisleri: Brazil: Amazonas: MZUSP 84994, 2, 20.43-22.21 mm SL, rio Tiquié, rio Negro basin. Hemigrammus levis: Brazil: Roraima: MZUSP 112920, 6, 28.87-35.09 mm SL, Caicubí stream, rio Negro basin. Hemigrammus ora: Brazil: Goiás: MZUSP 113814, 2,
31.35-31.73 mm SL, Monte Alegre de Goiás, rio Paranã, rio Tocantins basin. Hemigrammus parana: Brazil: Minas Gerais: MZUSP 82853, 3, 25.18-26.89 mm SL, Nova Ponte, rio Araguari, rio Paranaíba basin. Hemigrammus pretoensis: Brazil: Amazonas: MZUSP 17627, 6, 39.38-50.81 mm SL, Fonte Boa, rio Solimões basin. Hemigrammus unilineatus: Brazil: Pará: MZUSP 105777, 10, 28.8-37.2 mm SL, Barcarena, rio Tocantins basin. Hyphessobrycon cachimbensis: Brazil: Pará: MZUSP 101249, 15, 23.16-41.47 mm SL, Novo Progresso, rio Tapajós basin. Hyphessobrycon loweae: Brazil: Mato Grosso: MZUSP 95611, 14, 13.35-25.44 mm SL, Gaúcha do Norte, rio Culuene, rio Xingu basin. Hyphessobrycon melanostichos: Brazil: Mato Grosso: MZUSP 110406, 11, 22.62-28.91 mm SL, Nobres, Lagoa Azul, rio Paraguay basin. Hyphessobrycon moniliger: Brazil: Goiás: MZUSP 113810, 15, 18.71-27.68 mm SL, Monte Alegre de Goiás, rio Paranã, rio Tocantins basin. Jupiaba acanthogaster: Brazil: 
Mato Grosso do Sul: MZUSP 83586, 2, 21.11-47.25 mm SL, Coxim, rio Capivari, rio Paraguay basin. Jupiaba apenima: Brazil: Tocantins: MZUSP 113831, 1, 40.46 mm SL, Almas, Rio do Peixe, rio Tocantins basin. Paratypes of Moenkhausia aurantia Bertaco, Jerep \& Carvalho, 2011: Brazil: Goiás: MZUSP 107827, 8, 27.740.0 mm SL, Nova Roma, rio Tocantins basin. MZUSP 113835, 25, 33.0-49.5 mm SL, São João da Aliança, rio Tocantins basin. Paratypes of Moenkhausia bonita Benine, Castro \& Sabino, 2004: Brazil: Mato Grosso do Sul: LIRP 4273, 2, 31-41.2 mm SL, rio Paraguay basin; Holotype of Moenkhausia chlorophthalma Sousa, Netto-Ferreira \& Birindelli, 2010: Brazil: Pará: MZUSP 99412, 67.2 mm SL, rio Xingu basin. Moenkhausia cosmops: Brazil: Mato Grosso: LIRP 8181, 2, 44.9-53.7 mm SL, Sapezal, rio Tapajós basin. Moenkhausia cotinho: Brazil: Mato Grosso: LIRP 8179, 2, 37.2-41.1 mm SL, Sapezal, rio Tapajós basin. Moenkhausia heikoi: Brazil: Pará: MZUSP 83536, 1, 46.8 mm SL, Altamira, rio Xingu basin. Moenkhausia hemigrammoides: Brazil: Amazonas: MZUSP 92501, 10, 27.0-32.7 mm SL, rio Negro basin. Paratype of Moenkhausia nigromarginata Costa, 1994: Brazil: Mato Grosso: MZUSP 45289, 1, $40.1 \mathrm{~mm}$ SL, rio Juruena, rio Tapajós basin. Moenkhausia oligolepis: Brazil: Mato Grosso: LIRP 7672, 2, 69.4-70 mm SL, Sapezal, rio Juruena, rio Tapajós basin. Moenkhausia phaeonota: Brazil: Mato Grosso: LIRP 7658, 2, 21.1-25 mm SL, Sapezal, rio Juruena, rio Tapajós basin. Moenkhausia pirauba: Brazil: Mato Grosso: LIRP 7653, 2, 75.8-90.6 mm SL, Sapezal, rio Juruena, rio Tapajós basin. Paratypes of Moenkhausia tergimacula Lucena \& Lucena, 1999: Brazil: Goiás: MCP 20287, 2, 34.7-49.3 mm SL, Minaçu, rio Tocantins basin. Pristella maxillaris: Brazil: Pará: MZUSP 18031, 49, 19.01-25.22 mm SL, Vila Maiauatá, rio Tocantins basin. Tetragonopterus carvalhoi: Brazil: Amapá: MZUSP 101803, 3, 55.11-62.78 mm SL, Laranjal do Jari, rio Jari basin. Tetragonopterus chalceus: Brazil: Pará: MZUSP 111878, 2, 42.92-55.99 mm SL, Altamira, rio Iriri, rio Xingu basin.

\section{Acknowledgments}

The authors are indebted to André Esguicero, who deposited an ichthyological collection from rio Juruena at LIRP. Ricardo Castro and Flávio Bockmann allowed us to use the equipment for image capture and digital illustration (FAPESP: 04/09219-6; 09/54931-0). We are grateful to José Luís O. Birindelli who made photographs (a) and (b) in Fig. 6 and to Rodrigo Ilário for the photograph (a) in Fig. 3. We thank Túlio Teixeira for confirming the sexual dimorphism found in Moenkhausia rubra. Lots MZUEL 8009, MZUSP 113835, MZUSP 114032 were collected during expeditions funded by the South American Characiformes Inventory (FAPESP 2011/50282-7, http://www.projeto-saci.com). We thank also Manoela Marinho, Osvaldo Oyakawa, and Priscila Camelier for help in the field. Authors were funded by FAPESP (2012/22685-2, MNLP; 2011/23419-1, FCPD).

\section{Literature Cited}

Benine, R. C., R. M. C. Castro \& J. Sabino. 2004. Moenkhausia bonita: a new small characin fish from the Rio Paraguay basin, southwestern Brazil (Characiformes: Characidae). Copeia, 2004: 68-73.
Benine, R. C., T. C. Mariguela \& C. Oliveira. 2009. New species of Moenkhausia Eigenmann, 1903 (Characiformes: Characidae) with comments on the Moenkhausia oligolepis species complex. Neotropical Ichthyology, 7: 161-168.

Bertaco, V. A. \& T. P. Carvalho. 2005a. New characid fish, Hemigrammus skolioplatus (Characiformes: Characidae) from upper rio Tapajós drainage, Central Brazil. Comunicações do Museu de Ciências e Tecnologia da PUCRS, Série Zoologia, 18: 141-150.

Bertaco, V. A. \& T. P. Carvalho. 2005b. A new characid fish, Hyphessobrycon hexastichos (Characiformes: Characidae) from Chapada dos Parecis, Mato Grosso, Brazil. Neotropical Ichthyology, 3: 439-443.

Bertaco, V. A. \& V.Garutti. 2007. New Astyanax from the upper rio Tapajós drainage, Central Brazil (Characiformes: Characidae). Neotropical Ichthyology, 5: 25-30.

Bertaco, V. A. \& L. R. Malabarba. 2007. A New Species of Hasemania from the Upper Rio Tapajós Drainage, Brazil (Teleostei: Characiformes: Characidae). Copeia, 2007: 350-354.

Bertaco, V. A., F. C. Jerep \& F. R. Carvalho. 2011a. New species of Moenkhausia Eigenmann (Ostariophysi: Characidae) from the upper Rio Tocantins basin in central Brazil. Neotropical Ichthyology, 9: 57-63.

Bertaco, V. A., F. C. Jerep \& F. R. Carvalho. 2011b. A new characid fish, Moenkhausia aurantia (Ostariophysi: Characiformes: Characidae), from the upper rio Tocantins basin in central Brazil. Zootaxa, 2934: 29-38.

Britski, H. A. \& J. C. Garavello. 2005. Uma nova espécie de Leporinus Agassiz, 1829, da bacia Amazônica (Ostariophysi: Characiformes: Anostomidae). São Paulo. Comunicações do Museu de Ciências e Tecnologia da PUCRS, Série Zoologia, 18: 75-83.

Britski, H. A. \& J. C. Garavello. 2007. Description of two new sympatric species of the genus Hisonotus Eigenmann and Eigenmann, 1889, from upper Rio Tapajós, Mato Grosso state, Brazil (Pisces: Ostariophysi: Loricariidae). Brazilian Journal of Biology, 67: 413-420.

Britski, H. A. \& F. C. T. Lima. 2008. A new species of Hemigrammus from the Upper Rio Tapajós Basin in Brazil (Teleostei: Characiformes: Characidae). Copeia, 2008: 565-569.

Carvalho, M. \& A. Datovo. 2012. A new species of cascudinho of the genus Hisonotus (Siluriformes: Loricariidae: Hypoptopomatinae) from the Upper Rio Tapajós Basin, Brazil. Copeia, 2012: 266-275.

Carvalho, T. P. \& V. A. Bertaco. 2006. Two new species of Hyphessobrycon (Teleostei: Characidae) from upper rio Tapajós basin on Chapada dos Parecis, Central Brazil. Neotropical Ichthyology, 4: 301-308.

Costa, W. J. E. M. 1994. Description of two new species of the genus Moenkhausia (Characiformes: Characidae) from the central Brazil. Zoologischer Anzeiger, 232: 21-29.

Eigenmann, C. H. 1903. New genera of South American fresh-water fishes and new names for some old genera. Smithsonian Miscellaneous Collections, 45: 144-148.

Eigenmann, C. H. 1917. The American Characidae - I. Memoirs of the Museum of Comparative Zoology, 43: 1-102.

Ferraris Jr., C. J. 2007. Checklist of catfishes, recent and fossil (Osteichthyes: Siluriformes), and catalogue of siluriform primary types. Zootaxa, 1418: 1-628.

Ferreira, K. M. \& A. L. Netto-Ferreira. 2010. Knodus dorsomaculatus (Characiformes: Characidae), a new species from Teles Pires River, Tapajós River basin, Brazil. Journal of Fish Biology, 77: 468-478 
Fink, W. L. 1979. A new species of Moenkhausia from the Mato Grosso region of Brazil (Pisces: Characidae). Breviora, 450: 112.

Fink, W. L. \& S. H. Weitzman. 1974. The so-called Cheirodontin fishes of Central America with descriptions of two new species (Pisces: Characidae). Smithsonian Contributions to Zoology, 172: 1-46.

Fisch-Muller, S., A. R. Cardoso \& V. A. Bertaco. 2005. Two new Amazonian species of armored catfishes (Siluriformes: Loricariidae): Ancistrus verecundus and Ancistrus parecis. Neotropical Ichthyology, 3: 525-532.

Géry, J. 1977. Characoids of the world. T. F. H. Publications, Neptune City, New Jersey.

Lima, F. C. T., L. R. Malabarba, P. A. Buckup, J. F. P. Silva, R. P. Vari, A. Harold, R. C. Benine, O. T. Oyakawa, C. S. Pavanelli, N. A. Menezes, C. A. S. Lucena, R. E. Reis, F. Langeani, L. Casatti, V. A. Bertaco, C. R. Moreira \& P. H. F. Lucinda. 2003. Genera Incertae Sedis in Characidae. Pp. 106-169. In: Reis, R. E., S. O. Kullander \& C. J. Ferraris Jr. (Eds.). Check List of the Freshwater fishes of South and Central America. Porto Alegre, Edipucrs.

Lima, F. C. T., H. A. Britski \& F. A. Machado. 2007. A new Moenkhausia (Characiformes: Characidae) from central Brazil, with comments on the area relationship between the upper rio Tapajós and upper rio Paraguai systems. Aqua, International Journal of Ichthyology, 13: 45-54.

Mariguela, T. C., R. C. Benine, K. T. Abe, G. S. Avelino \& C. Oliveira. 2013. Molecular phylogeny of Moenkhausia (Characidae) inferred from mitochondrial and nuclear DNA evidence. Journal of Zoological Systematics and Evolutionary Research, 51: 327-332.

Marinho, M. M. F. 2010. A new species of Moenkhausia Eigenmann (Characiformes: Characidae) from the rio Xingu basin, Brazil. Neotropical Ichthyology, 8: 655-659.

Marinho, M. M. F. \& F. Langeani. 2010. Moenkhausia celibela: a new species from the Amazon basin, Brazil (Characiformes: Characidae). Journal of Fish Biology, 77: 879-889.

Menezes, N. A. 2006. Description of five new species of Acestrocephalus Eigenmann and redescription of A. sardina and A. boehlkei (Characiformes: Characidae). Neotropical Ichthyology, 4: 385-400.
Mirande, J. M. 2010. Phylogeny of the family Characidae (Teleostei: Characiformes) from characters to taxonomy. Neotropical Ichthyology, 8: 385-568.

Oliveira, C., G. S. Avelino, K. T. Abe, T. C. Mariguela, R. C. Benine, G. Orti, R. P. Vari \& R. M. C. Castro. 2011. Phylogenetic relationships within the speciose family Characidae (Teleostei: Ostariophysi: Characiformes) based on multilocus analysis and extensive ingroup sampling. BMC Evolutionary Biology, 11: $1-25$.

Scharcansky, A. \& C. A. S. Lucena. 2007. Caenotropus schizodon, a new chilodontid fish from the Rio Tapajós drainage, Brazil (Ostariophysi: Characiformes: Chilodontidae). Zootaxa, 1557: 59-66.

Sousa, L. M., A. Netto-Ferreira \& J. L. O. Birindelli. 2010. Two new species of Moenkhausia Eigenmann (Characiformes: Characidae) from Serra do Cachimbo, Pará, Northern Brazil. Neotropical Ichthyology, 8: 255-264.

Taylor, W. R. \& G. C. Van Dyke. 1985. Revised procedures for staining and clearing small fishes and other vertebrates for bone and cartilage study. Cybium, 9: 107-119.

Varella, H. R., S. O. Kullander \& F. C. T. Lima. 2012. Crenicichla chicha, a new species of pike cichlid (Teleostei: Cichlidae) from the rio Papagaio, upper rio Tapajós basin, Mato Grosso, Brazil. Neotropical Ichthyology, 10: 233-244.

Vari, R. P., C. J. Ferraris Jr. \& M. C. C. de Pinna. 2005. The Neotropical whale catfishes (Siluriformes: Cetopsidae: Cetopsinae), a revisionary study. Neotropical Ichthyology, 3: 127-238.

Vazzoler, A. E. A. M. 1996. Biologia da reprodução de peixes Teleósteos: teoria e prática. Maringá, Eduem.

Weitzman, S. H. \& L. Palmer. 1997. A new species of Hyphessobrycon (Teleostei: Characidae) from the Neblina region of Venezuela and Brazil, with comments on the putative 'rosy tetra clade'. Ichthyological Exploration of Freshwaters, 7: 209242.

Zanata, A. M., J. L. O. Birindelli \& C. R. Moreira. 2009. New species of Moenkhausia Eigenmann (Characiformes:Characidae) from Rio Xingu and Rio Tapajós basins, Brazil, with comments on a putative case of polymorphic Batesian mimicry. Journal of Fish Biology, 75: 2615-2628.

Submitted October 10, 2013 Accepted April 24, 2014 by George Mattox Published June 30, 2014 